\title{
REGENERASI RUMPUT LAUT Kappaphycus alvarezii HASIL TRANSFORMASI GEN Sitrat Sintase MENGGUNAKAN Agrobacterium tumefaciens SECARA IN VITRO
}

\author{
Emma Suryati ${ }^{*}$, Ristanti Frinra Daud ${ }^{* *}$, Utut Widyastuti**), Andi Tenriulo", \\ dan Andi Parenrengi*) \\ *) Balai Penelitian dan Pengembangan Budidaya Air Payau \\ Jl. Makmur Dg. Sitakka No. 129, Maros 90512, Sulawesi Selatan \\ E-mail: emmasuryati@yahoo.com \\ $\left.{ }^{* *}\right)$ Pusat Penelitian Sumberdaya Hayati dan Bioteknologi, IPB, dan \\ Departemen Biologi, FMIPA IPB \\ Jl. Lingkar Akademik, Kampus IPB Darmaga, Bogor 16680
}

(Naskah diterima: 20 Januari 2014; Disetujui publikasi: 19 Juni 2014)

\begin{abstract}
ABSTRAK
Introduksi gen sitrat sintase pada rumput laut Kappaphycus alvarezii menggunakan Agrobacterium tumefaciens telah dilakukan secara in vitro. Introduksi gen sitrat sintase ke dalam genom rumput laut dapat mengurangi cekaman oksidatif terutama perubahan yang disebabkan oleh perubahan suhu, salinitas dan cemaran logam di perairan. Penelitian ini bertujuan dalam rangka perbanyakan rumput laut hasil introduksi gen sitrat sintase melalui teknik kultur jaringan pada media cair dan media semi solid. Regenerasi tunas dilakukan berdasarkan eksplan yang tahan pada media seleksi higromisin serta evaluasi transgenik dilakukan menggunakan teknik PCR, di bawah kendali promoter 35S CaMV. Hasil penelitian memperlihatkan efisiensi transformasi pada media selektif sebanyak $30 \%$, efisiensi regenerasi thalus transgenik pada media seleksi $85 \%$, dan efisiensi regenerasi thalus non transgenik sebesar $95 \%$ pada media non selektif. Media recovery dengan penambahan pupuk PES memperlihatkan sintasan yang paling baik pada regenerasi thalus transgenik. Hasil analisis PCR memperlihatkan $K$. alvarezii transgenik putatif mengandung transgen $P a C S$ di bawah kendali promoter 35S CaMV.
\end{abstract}

KATA KUNCl: Kappaphycus alvarezii, rumput laut, gen PaCs, transformasi

ABSTRACT: Regeneration of seaweed Kappaphycus alvarezii resulting from citrate synthase gene transformation with Agrobacterium tumefaciens by in vitro methode. By: Emma Suryati, Ristanti Frinra Daud, Utut Widyastuti, Andi Tenriulo, and Andi Parenrengi

Introduction of citrate synthase gene in seaweed Kappaphycus alvarezii using Agrobacterium tumefaciens has been done in vitro. Introduction of citrate synthase gene into the genome of seaweed can reduce oxidative stress changes which are, caused primarily by changes in temperature, salinity and metal contamination in the waters. The aim of this research was to propagate the seaweed resulting from introduction of citrate synthase gene through tissue culture techniques on liquid media and semi-solid media. Regeneration of the bud was done by explants which were resistant to the hygromycin selection media and the evaluation of performed transgenic using PCR techniques, under the control of the CaMV 355 promoter. The results demonstrated that the efficiency of the transformation on selective media 
was $30 \%$, the efficiency of regeneration of the transgenic thalus on selection media was $85 \%$, while the non-transgenic thalus regeneration efficiency was $95 \%$ on nonselective media. Recovery media with the addition of PES fertilizer showed the best survival in transgenic thalus regeneration. PCR analysis results showed the putative transgene of K. alvarezii containing PaCS transgenic under control of $35 \mathrm{~S} \mathrm{CaMV}$ promoter.

\section{KEYWORDS: Kappaphycus alvarezii, seaweed, PaCs gene, transformation}

\section{PENDAHULUAN}

Perubahan mutu lingkungan yang ekstrim dapat menyebabkan pertumbuhan rumput laut terganggu dan memicu serangan penyakit iceice sehingga dapat menurunkan produksi. Penyakit ice-ice seringkali disebabkan oleh perubahan mutu lingkungan antara lain pergantian musim, serta masuknya limbah pemukiman, pertanian, limbah pabrik, kegiatan perikanan ke perairan sehingga mempengaruhi kondisi ekologis perairan (Collen, 1995). Penyakit tersebut lebih mengindikasikan stres daripada serangan patogen. Hal ini didukung dengan ditemukan fakta bahwa penyakit iceice lebih menonjol pada lingkungan yang kualitas airnya rendah, pergantian air sedikit, salinitas rendah dan tinggi rendahnya suhu air serta kandungan logam berat yang tinggi di perairan (Mtolera et al., 1995). Cemaran logam yang sering dijumpai pada sedimen dan perairan pantai antara lain $\mathrm{Bp}, \mathrm{Cd}, \mathrm{Cu}, \mathrm{Zn}, \mathrm{Mn}$, dan Al (Jickells, 1955; De Baar \& La Roche, 2003, dan Rochyatun \& Rozak, 2007).

Dalam rangka meningkatkan dan mempertahankan produksi rumput laut nasional perlu dilakukan upaya-upaya dalam mengatasi permasalahan dalam budidaya, seperti menurunnya mutu genetik rumput laut akibat permasalahan penyakit dan lingkungan (Largo et al., 1997; Vairappan, 2006) melalui beberapa pendekatan teknologi, antara lain rekayasa genetik melalui transformasi gen potensial yang dapat meningkatkan ketahanan serta memperbaiki gen dari rumput laut.

Rumput laut $K$. alvarezii dan Eucheuma spinosum merupakan alga yang mampu mengabsorpsi logam (Diantariani et al., 2008), namun pada konsentrasi tertentu jaringan rumput laut tidak mampu lagi untuk bertahan sehingga cekaman logam berat berupa Aluminium (Al) menyebabkan perubahan struktur sel yang meliputi reduksi jumlah butir pati dalam nukleoplas, inti sel tersegmentasi, dan adanya kondensasi kromosom pada inti (Nagy et al., 2004), serta kerusakan pada membran plasma. Cekaman Al mengakibatkan membran plasma kehilangan integritasnya (Yamamoto et al., 2001), yang selanjutnya dapat memicu gangguan penyerapan hara dan air sehingga menyebabkan defisiensi unsur hara. Untuk mengatasi hal tersebut, perlu dilakukan upaya untuk meningkatkan ketahanan rumput laut terhadap cekaman logam berat melalui peningkatan produksi asam sitrat pada rumput laut $K$. alvarezii.

Asam sitrat dihasilkan dari siklus Kreb atau siklus asam sitrat. Pada siklus ini, diawali dengan pengubahan pirufat menjadi asetil KoA dengan melepaskan $\mathrm{CO}_{2}$. Asetil KoA akan bereaksi dengan oksaloasetat yang berkarbon empat menjadi senyawa berkarbon enam sitrat. Enzim yang berperan dalam reaksi ini adalah sitrat sintase (Taiz \& Zeiger, 2002). Beberapa spesies dari genus Pseudomonas dimanfaatkan sebagai pelarut fosfat, yaitu dengan mensekresikan asam organik terutama sitrat (Buch et al., 2008). Gen sitrat sintase asal Pseudomonas aeuginosa ( $\mathrm{PaCs}$ ) yang berukuran 1.287 bp dan menyandikan 428 asam amino telah berhasil diisolasi dan diintroduksikan ke dalam tanaman Nicotiana tabacum dan Jatropha curcas melalui perantaraan Agrobacterium tumefaciens. Hasil uji tantang tembakau transgenik dengan cekaman Al menunjukkan bahwa tanaman transgenik yang mengandung gen $\mathrm{PaCs}$ lebih toleran dibandingkan dengan tanaman non transgenik (Tistama, 2012).

Beberapa peneliti telah menggunakan $A$. tumefaciens sebagai perantara transformasi, seperti yang dilakukan oleh Cheng et al. (2011) pada mikroalga Schizochytrium. Pengembangan teknologi kultur jaringan merupakan salah satu teknologi yang mendukung rekayasa genetik pada tanaman. Teknik kultur jaringan rumput laut Kappaphycus alvarezii telah dikembangkan oleh Suryati \& Mulyaningum (2009).

Tujuan penelitian ini adalah melakukan regenerasi dan perbanyakan rumput laut hasil 
transformasi gen PaCS menggunakan bakteri A. tumefaciens secara in vitro.

\section{BAHAN DAN METODE}

Penelitian ini dilakukan, di laboratorium Bioteknologi Balai Penelitian dan Pengembangan Budidaya Air Payau (BPPBAP) Maros, Laboratorium Biotechnology Research Indonesia-Netherland (BIORIN), dan Pusat Penelitian Sumberdaya Hayati dan Bioteknologi (PPSHB), Institut Pertanian Bogor.

Rumput laut $K$. alvarezii yang digunakan sebagai tanaman yang akan diintroduksi dengan gen sitrat sintase diperoleh dari hasil budidaya rumput laut di Kabupaten Takalar, Sulawesi Selatan.

Bakteri A. tumefaciens LBA4404 yang membawa plasmid pMSH-PaCs digunakan untuk menginokulasi rumput laut $K$. alvarezii. Peta fisik daerah T-DNA yang terdapat gen $\mathrm{PaCs}$ di bawah kendali promoter 35S CaMV disajikan pada (Gambar 1). Primer spesifik PaCS-F (5'ATGGCTG-ACAAAAAAGCGCAG3'), PaCs-R (5'TCAGCCGCGATCCTTGAG GGC3') dan 35S-F (5'AAACCTCCTCGATTCC-ATT3') digunakan untuk mengetahui keberadaan gen $\mathrm{PaCs}$ di bawah kendali promoter 35S CaMV.

\section{Persiapan Eksplan}

Thalus $K$. alvarezii yang akan digunakan diseleksi dengan seksama, dipilih thalus yang sehat berwarna cerah dan tidak berlumut, dipotong sepanjang $2 \mathrm{~cm}$ dan dibersihkan dengan air laut yang disaring dengan filter UV. Thalus dibersihkan dengan sikat di bawah mikroskop, kemudian disterilisasi dengan betadin $1 \%$ di dalam air laut steril selama satu menit, kemudian disterilisasi menggunakan campuran antibiotik (penisilin-Meiji, kanamisinMeiji, streptomisin-Phytotech, ripamficinBiobasic.inc) masing-masing dengan konsentrasi 0,05\%) untuk menghilangkan mikroba permukaan. Thalus yang telah dipotong dikultur pada air laut steril yang diperkaya dengan provasoly enriched seawater (PES) dengan foto periode 12 jam. Untuk inisiasi dan penyesuaian pada kondisi laboratorium.

\section{Kultur A. tumefaciens}

A. tumefaciens yang membawa gen $\mathrm{PaCs}$ dikultur dalam $3 \mathrm{~mL}$ media LB (20\% Bacto tryptone (Difco), $10 \%$ Bacto yeast (Difco), 20\% $\mathrm{NaCl}$ (Merck) yang mengandung antibiotik 50 $\mathrm{\mu g} / \mathrm{mL}$ streptomycin-phytotech, $50 \mu \mathrm{g} / \mathrm{mL}$ kanamycin-Meiji, $50 \mu \mathrm{g} / \mathrm{mL}$ hygromysinphytotech dan diinkubasi dengan pengocok (IKA-shaker) dengan kecepatan $250 \mathrm{rpm}$, suhu $28^{\circ} \mathrm{C}$ selama 48 jam di ruang gelap. Biakan disubkultur lagi setelah 48 jam di dalam $20 \mathrm{~mL}$ LB selama 16 jam dengan kondisi yang sama. Kultur A. tumefaciens selanjutnya dimasukkan ke dalam tabung masing-masing $1,5 \mathrm{~mL}$ disentrifugasi dengan kecepatan $4.000 \mathrm{rpm}$ (Mikro 22R Hettich) selama lima menit, kemudian endapannya diresuspensi dengan $20 \mathrm{~mL}$ media kokultivasi cair (20 mL/L PES; 20 part per thousand (ppt) air laut steril; $100 \mu \mathrm{M}$ asetosiringon-phytotech; $0,05 \mathrm{~g} / 100 \mathrm{~mL}$ glukosa-Merck) hingga nilai optical density $\left(\mathrm{OD}_{600}\right)$ 0,5.

\section{Transformasi Genetik K. alvarezii}

Prosedur transformasi pada rumput laut ini dilakukan dengan menggunakan thalus rumput laut yang dipotong-potong dengan ukuran $0,5 \mathrm{~cm}$ dan diadaptasikan terlebih dahulu pada media padat PES 0,8\% (20 mL/L PES; 30 ppt air laut steril; 0,8\% bacto agar-difco) selama 3-5 hari. Transformasi dimulai dengan mencuci potongan thalus menggunakan air laut steril 30 ppt, kemudian dikeringkan pada tisu steril. Thalus rumput laut $K$. alvarezii disiapkan sebanyak 400 eksplan yang tidak diinokulasi/transformasi, dan 400 eksplan yang akan diinokulasi/transformasi, transformasi dilakukan dengan cara direndam dalam biakan A. tumefaciens LBA4404 yang membawa plasmid pMSH-PaCs dalam media inokulasi (20 ppt air laut steril; 20 mL/L PES; $100 \mu \mathrm{M}$ asetosiringon-phytotech; $0,05 \mathrm{~g} / 100 \mathrm{~mL}$ glukosa-Merck) selama 15 menit. Thalus selanjutnya dikeringkan, pada tisu steril dan dipindahkan dalam media ko-kultivasi padat (25 ppt air laut; 0,3\% gelrite; $100 \mu \mathrm{M}$ asetosiringon; $0,05 \mathrm{~g} / 100 \mathrm{~mL}$ glukosa) dan diinkubasi dalam

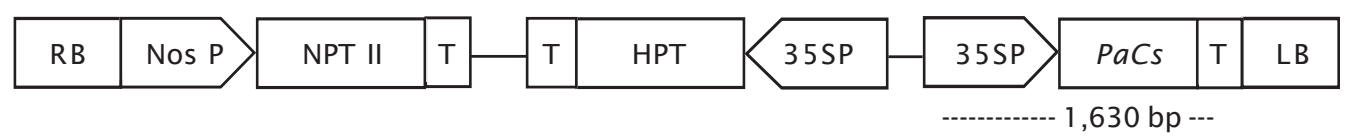

Gambar 1. Konstruksi gen PaCs di dalam vektor ekspresi pMSH (Tistama, 2012)

Figure 1. Construction of PaCs gene in pMSH expressing vector (Tistama, 2012) 
ruangan gelap selama 2-3 hari. Thalus selanjutnya direndam di dalam air laut steril yang mengandung $200 \mathrm{mg} / \mathrm{L}$ cefotaxim selama sepuluh menit, setelah itu thalus dibersihkan dan ditanam dalam media recovery (30 ppt air laut steril; $20 \mathrm{~mL} / \mathrm{L}$ PES; 0,4\% bacto agar-Difco). Thalus yang tidak diinokulasi dengan bakteri A. tumefaciens LBA4404 yang membawa plasmid pMSH-PaCs disiapkan sebagai pembanding. Setelah 1-2 minggu, thalus dipindahkan ke media seleksi padat (air laut steril 30 ppt; PES $20 \mathrm{~mL} / \mathrm{L}$; bacto agar 0,5\%; higromisinphytotech $10 \mathrm{mg} / \mathrm{L})$. Thalus tersebut dibiakkan di media PES cair tanpa antibiotik (20 $\mathrm{mL} / \mathrm{L}$ PES; 30 ppt air laut steril) di ruang kultur jaringan hingga beregenerasi membentuk tunas 1-2 minggu. Kandidat transgenik rumput laut yang membawa gen $\mathrm{PaCS}$ selanjutnya akan diperbanyak melalui teknik kultur jaringan menggunakan media cair dan media semi solid.

\section{Analisis Integrasi Gen PaCs di dalam K. alvarezii}

Analisis integrasi gen $P a C s$ di dalam genom $K$. alvarezii transgenik dilakukan dengan PCR. DNA genom diperoleh dari tunas putatif yang dihasilkan dari proses regenerasi hasil transformasi, diisolasi yang mengunakan teknik isolasi Wattier et al. (2000). Reaksi PCR dilakukan dengan mencampurkan 100 ng DNA genom, 0,5 mM kombinasi primer gen spesifik sitrat sintase PaCs-F dan PaCs-R, serta 0,5 mM kombinasi primer 35s-F dan PaCs-R, $5 \mu \mathrm{L}$ PCR mix, ditambah dengan $\mathrm{dd}_{2} \mathrm{O}$ hingga volume $10 \mu \mathrm{L}$. Kondisi PCR adalah denaturasi selama 30 detik pada suhu $95^{\circ} \mathrm{C}$, annealing selama 30 detik pada suhu $55^{\circ} \mathrm{C}$, dan ekstensi pada suhu $72^{\circ} \mathrm{C}$ selama dua menit sebanyak 35 siklus. Sebanyak $5 \mathrm{~mL}$ hasil PCR dielektroforesis menggunakan gel agarose $1 \%$ dengan voltase 100 volt selama 30 menit dan selanjutnya gel direndam dalam etidium bromide 0,5 $\mathrm{mg} \mathrm{L}^{-1}$ selama 20 menit, direndam 20 menit dengan air kemudian divisualisasi dengan UV transiluminator. Keberhasilan integrasi gen PaCs pada rumput laut $K$. alvarezii ditandai dengan pita pada 1.300 bp pada gel elektroforesis hasil PCR.

\section{Regenerasi Rumput Hasil Transformasi Gen PaCs pada Media Cair dan Semi Solid}

Eksplan rumput laut hasil transformasi yang mengandung gen $\mathrm{PaCs}$, dipindahkan pada media semi solid yang diperkaya dengan pu- puk PES. Regenerasi dan pemeliharaan eksplan rumput laut hasil transgenik, dilakukan pada labu yang dilengkapi dengan aerasi, diletakkan di dalam culture chamber pada suhu $20^{\circ} \mathrm{C}$ dengan media cair yang diperkaya dengan pupuk PES, Grund, dan SSW sebagai kontrol. Pengkayaan dengan pupuk tersebut merupakan perlakuan yang diulang masingmasing tiga kali menggunakan desain RAL. Dalam rangka memacu pertumbuhan tunas dan cabang rumput laut, selanjutnya media terbaik pada tahapan regenerasi diperkaya dengan kombinasi Indol Acetic Acid (IAA) dan Benzyl Amino Purin (BAP) dengan beberapa konsentrasi antara lain $1: 1,1: 2$, dan $2: 1$, serta diamati pengaruh derajat keasaman $(\mathrm{pH})$ dengan kisaran 4,6 , dan 8 , sedangkan ratio gelap terang (photopheriod) antara lain dengan perbandingan $18: 6,12: 12$, dan $6: 18$ pada pemeliharaan anakan rumput laut transgenik.

Keberhasilan regenerasi ditandai dengan pertumbuhan dan perkembangan tunas serta cabang rumput laut hasil transgenik serta sintasan dari eksplan yang dipelihara pada media kultur yang disediakan.

\section{HASIL DAN BAHASAN}

\section{Transformasi Genetik K. alvarezii dengan Gen Sitrat Sintase}

Hasil transformasi gen $\mathrm{PaCS}$ ke dalam genom $K$. alvarezii melalui perantara A. tumefaciens memperlihatkan pertumbuhan yang baik pada media seleksi, media ko-kultivasi dan media recovery pada tahapan transformasi gen pada rumput laut (Gambar 2). Thalus yang digunakan untuk transformasi dipilih yang sehat dan berkualitas baik, serta stabil pada media adaptasi di laboratorium. Eksplan yang dapat mendukung keberhasilan transformasi adalah eksplan yang segar dan sehat karena kerusakan pada jaringan thalus mengakibatkan thalus tidak dapat beradaptasi dengan baik dan mudah terkontaminasi oleh bakteri, sehingga menyebabkan kematian. Transformasi menggunakan $A$. tumefaciens memiliki beberapa kelebihan yaitu diantaranya mudah dilakukan (Hiei \& Komari, 2008).

Transformasi dilakukan berdasarkan kemampuan A. tumefaciens mentransfer T-DNA ke dalam kromosom tanaman, sebelumnya transformasi genetik menggunakan $A$. tumefaciens telah dilakukan pada marine makroalaga yaitu Porphyra yezoensis (Cheney et al., 2011). Penggunaan cefatoxim dimak- 

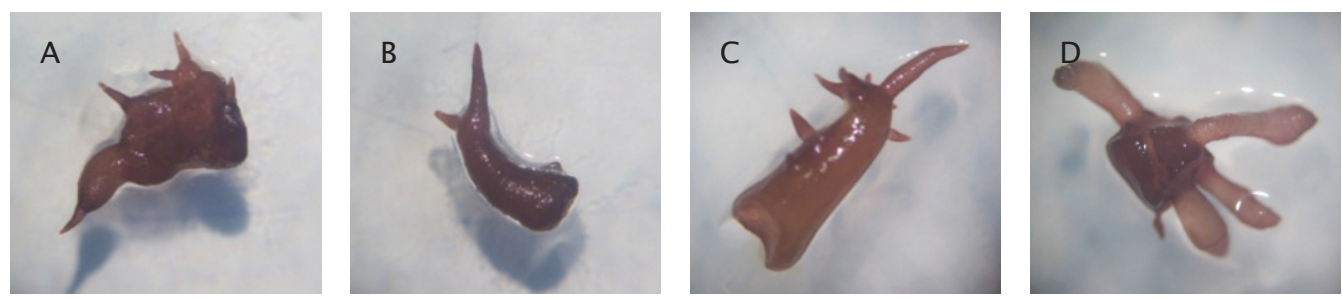

Gambar 2. Perkembangan transformasi rumput laut K. alvarezii menggunakan Agrobacterium tumefaciens pada $\mathrm{A}=$ media ko-kultivasi padat; $\mathrm{B}=$ media recovery; $\mathrm{C}=$ media seleksi mengandung higromisin $10 \mathrm{mg} / \mathrm{L} ; \mathrm{D}=$ media regenerasi (PES cair) tanpa higromisin

Figure 2. Development of Agrobacterium tumefaciens transformed thalli Kappaphycus alvarezii on solid co-cultivation medium (A); recovery medium (B); selection medium containing $10 \mathrm{mg} / \mathrm{mL}$ hygromycin (C); regeneration medium (liquid PES) without hygromycin (D)

sudkan untuk menghilangkan bakteri $A$. tumefaciens pada rumput laut sehingga diperoleh rumput laut dengan sisipan gen PaCS yang dibawa oleh bakteri $A$. tumefaciens.

Konsentrasi cefotaxim yang digunakan pada penelitian ini mengacu pada (Daud et al., 2013), lebih rendah daripada penggunaan konsentrasi cefotaxim pada penelitian tanaman tingkat tinggi, fungsi dari cefotaxim adalah untuk menghilangkan bakteri $A$. tumefaciens yang membawa gen $\mathrm{PaCs}$. Konsentrasi cefotaxim yang efektif digunakan dalam mengurangi jumlah bakteri pada tanaman tingkat tinggi berkisar 250-1500 $\mu \mathrm{g} /$ $\mathrm{mL}$ (Da silva \& Fukai, 2001). Hasil penelitian Okkels \& Paderson (1988) menunjukkan bahwa cefotaxim dalam konsentrasi yang tinggi dapat bersifat phytotoxic pada perkembangan tanaman Bit, namun pada dosis tertentu penggunaan cefotaxim pada proses transformasi tidak menghambat regenerasi tanaman (Koronfel, 1998).

Thalus transgenik putatif merupakan thalus yang dapat bertahan pada media seleksi higromisin, konsentrasi higromisin yang digunakan $10 \mathrm{mg} / \mathrm{L}$ mengacu pada konsentrasi yang digunakan oleh Daud (2013), persentase efisiensi transformasi yang diperoleh pada kegiatan ini mencapai 30\%, lebih besar dari yang diperoleh Daud (2013) dan Handayani (2013) yang memperoleh efisiensi tranformasi pada K.alvarezii hanya $7,5 \%$ dan $23 \%$. Hal ini kemungkinan disebabkan perbedaan kondisi thalus pada saat transformasi serta perbedaan ketahanan rumput laut terhadap antibiotik, sedangkan efisiensi regenerasi thalus putatif yang diperoleh hanya $83 \%$ dari jumlah eksplan yang resisten pada media higromisin, sedang- kan efisiensi regenerasi thalus non transgenik sebesar 95\% pada media non selektif yang tidak mengandung higromisin (Tabel 1). Efisiensi regenerasi yang diperoleh lebih rendah dari efisiensi regenerasi yang dihasilkan oleh Daud (2013) sebesar 100\%, namun lebih besar bila dibandingkan dengan hasil penelitian Handayani (2013) yang memperoleh efisiesi regenerasi $11,32 \%$. Hal ini kemungkinan disebabkan oleh beberapa faktor antara lain perbedaan kondisi serta ketahanan thalus terhadap infeksi bakteri, kondisi media kultur yang digunakan, serta konsentrasi antibiotik yang digunakan, selain itu sensitivitas sel tanaman terhadap agen seleksi bergantung pada genotip, tipe eksplan dan kondisi kultur jaringan (Koronfel, 1998).

Regenerasi rumput laut hasil transformasi gen PaCs dilakukan pada media recovery semi solid yang diperkaya dengan pupuk PES, Grund, dan SSW. Hasil penelitian memperlihatkan sintasan yang paling tinggi pada media PES, berbeda nyata dengan SSW, namun tidak berbeda nyata dengan media Grund (Gambar 3). Hal ini disebabkan kebutuhan nutrien pada rumput laut dapat dipenuhi oleh nutrien yang berada pada media yang diperkaya dengan PES, selain itu eksplan yang digunakan memang diadaptasi pada media dengan pupuk yang sama sehingga tidak perlu menyesuaikan diri dengan lingkungannya sendiri.

Regenerasi explan rumput laut hasil transformasi pada media cair yang diinkubasi di dalam culture chamber pada suhu $20^{\circ} \mathrm{C}$. memperlihatkan pertumbuhan tunas yang lebih cepat pada media PES, namun pada media yang diperkaya dengan pupuk Grund, se- 
Tabel 1. Efisiensi transformasi dan regenerasi rumput laut $K$. alvarezii mengandung gen citrate syntase

Table 1. The efficiency of transformation and regeneration of $\mathrm{K}$. alvarezii containing citrate syntase gene

\begin{tabular}{lccccc}
\hline $\begin{array}{c}\text { Perlakuan } \\
\text { Treatments }\end{array}$ & $\begin{array}{c}\text { Jumlah } \\
\text { eksplan awal } \\
\text { Number of } \\
\text { initial } \\
\text { explants }\end{array}$ & $\begin{array}{c}\text { Jumlah eksplan } \\
\text { tahan higromisin } \\
\text { Number of hygro- } \\
\text { mycin resistant } \\
\text { explants }\end{array}$ & $\begin{array}{c}\text { Persentase } \\
\text { transformasi } \\
\text { Percentage of } \\
\text { tranformation } \\
\text { (\%) }\end{array}$ & $\begin{array}{c}\text { Jumlah eksplan } \\
\text { regenerasi } \\
\text { Number of } \\
\text { regeneration } \\
\text { explant }\end{array}$ & $\begin{array}{c}\text { Efisiensi } \\
\text { regenerasi } \\
\text { Efficiency of } \\
\text { regeneration } \\
\text { (\%) }\end{array}$ \\
\hline $\begin{array}{l}\text { Diinokulasi } \\
\text { Inoculated }\end{array}$ & 400 & 120 & $30^{\text {a) }}$ & 120 & $83^{\mathrm{b})}$ \\
$\begin{array}{l}\text { Tidak diinokulasi } \\
\text { Not inoculated }\end{array}$ & 400 & 0 & 0 & 380 & $95^{\mathrm{c}}$ \\
\hline
\end{tabular}

Keterangan (Note):

a) Jumlah eksplan tahan higromisin/jumlah eksplan $x$ 100\% (The number of hygromycin resistant explants/number of explants $\times 100 \%$

b) Jumlah eksplan yang bertunas/jumlah eksplan tahan higromisin $\times 100 \%$ (The number of sprouted explants/number of hygromycin resistant explants $\times 100 \%)$

c) Jumlah eksplan yang bertunas/jumlah eksplan awal yang ditanam pada media tanpa higromisin $\times 100 \%$ The number of sprouted explants/number of initial explants grown on media without hygromycin $\times 100 \%$

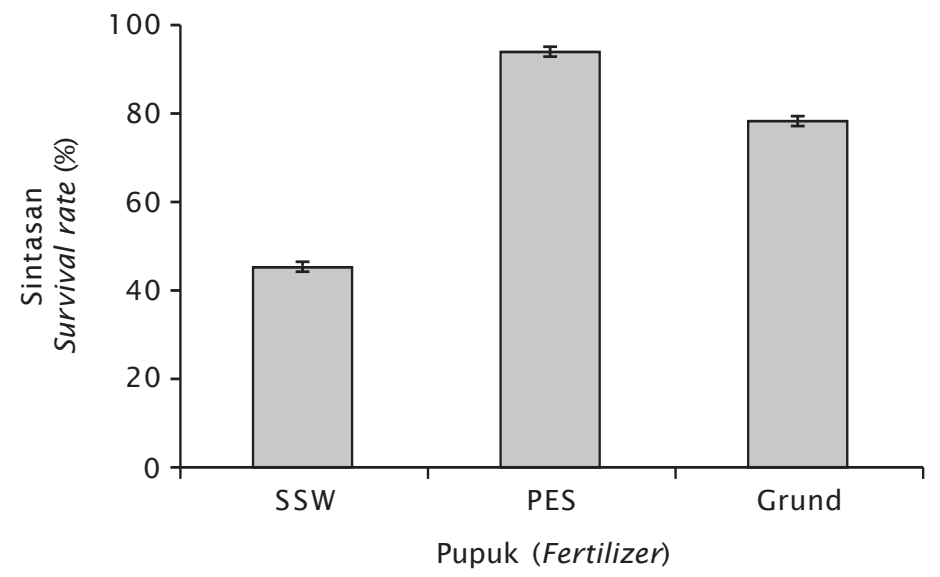

Gambar 3. Sintasan rumput laut hasil transformasi gen PaCs pada media kultur dengan pupuk yang berbeda

Figure 3. Survival of seaweed PaCs gene transformation in culture media with different fertilizer

cara visual memperlihatkan tampilan warna thalus rumput laut yang lebih cerah dan segar serta warna yang lebih coklat.

Pengaruh derajat keasaman $(\mathrm{pH})$ pada regenerasi rumput laut hasil transgenik memperlihatkan sintasan yang paling baik yaitu pada $\mathrm{pH}=6$, walaupun tidak berbeda nyata dengan $\mathrm{pH}=8$. (Gambar 4).
Ratio gelap terang (Photopheriod) pada regenerasi dan pemeliharaan anakan rumput laut hasil transgenik merupakan faktor penunjang pertumbuhan dan sintasan anakan rumput laut tersebut. Hasil pengamatan memperlihatkan sintasan yang paling baik yaitu pada perbandingan gelap dan terang 12:12, dan sintasan yang paling rendah yaitu pada perbandingan 16:8. (Gambar 5). 


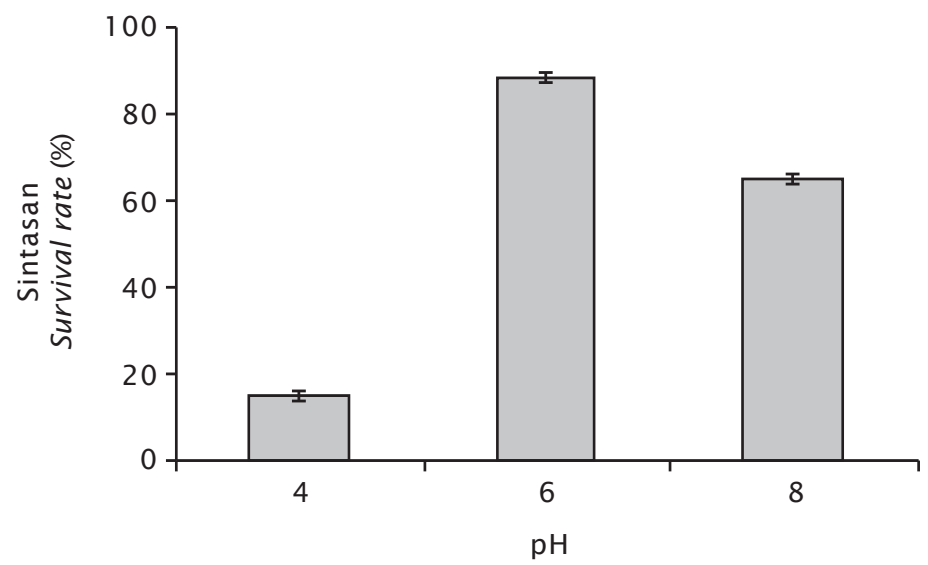

Gambar 4. Sintasan rumput laut hasil transformasi gen $\mathrm{PaCs}$ pada media PES dengan $\mathrm{pH}$ yang berbeda

Figure 4. Survival of seaweed PaCs gene transformation in PES media with different $\mathrm{pH}$

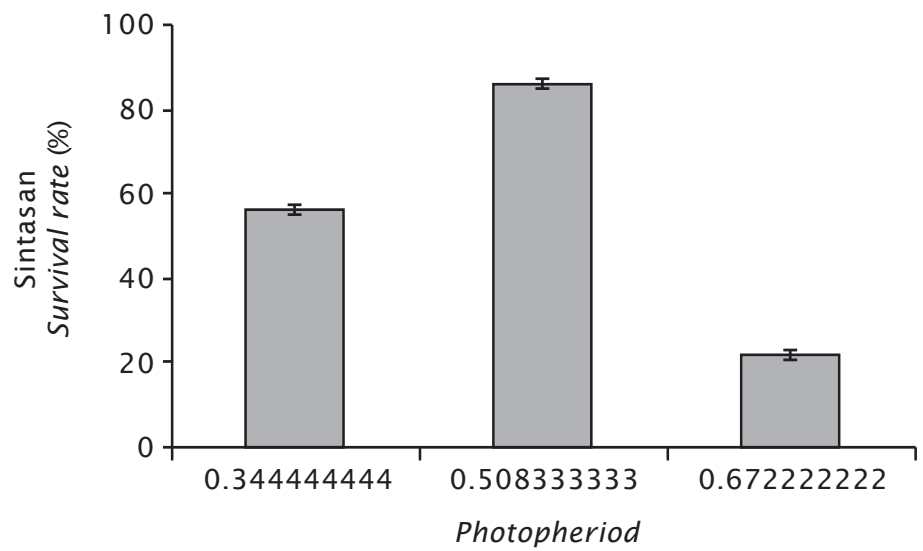

Gambar 5. Sintasan rumput laut hasil transformasi gen $\mathrm{PaCs}$ pada media PES dengan photopheriod yang berbeda

Figure 5. Survival of seaweed PaCs gene transformation in PES media with different photopheriod

\section{Analisis Integrasi Gen PaCs di dalam \\ K. alvarezii}

Dari thalus yang menghasilkan tunas transgenik putative pada media regenerasi, diambil beberapa tunas untuk diisolasi DNAnya. Hasil isolasi DNA genom dari tunas $K$. alvarezii transgenik putatif pada media regenerasi menunjukkan bahwa DNA tersebut memiliki kualitas yang baik (Gambar 6). DNA genom dari salah satu tunas transgenik putatif selanjutnya digunakan untuk analisis integrasi gen $P a C s$ pada K. alvarezii.
Analisis integrasi gen $\mathrm{PaCs}$ di dalam rumput laut menggunakan teknik PCR dengan primer gen $\mathrm{F} P a C s$ dan $\mathrm{R} P a C s$ menghasilkan pita berukuran $1.300 \mathrm{bp}$, sedangkan pada K. alvarezii non transgenik tidak menghasilkan pita tersebut. Hal ini menunjukkan bahwa primer tersebut dapat digunakan untuk mengetahui keberadaan transgen $\mathrm{PaCs}$ di $\mathrm{K}$. alvarezii transgenik (Gambar 7). Hasil ini juga menunjukkan bahwa rumput laut $K$. alvarezii mempunyai urutan nukleotida yang berbeda dengan gen PaCs dari Pseudomona aeruginosa. PCR dengan 


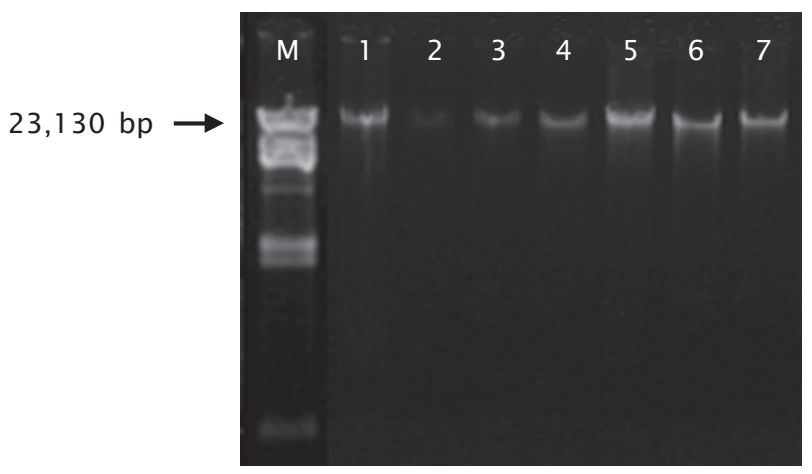

Gambar 6. Elektroforesis DNA genom rumput laut K. alvarezii. $\mathrm{M}=$ marker; 1-7 = sampel DNA rumput laut

Figure 6. Electrophoresis of DNA genome $\mathrm{K}$. alvarezii. $M=$ Marker DNA; 1-7 = DNA sample

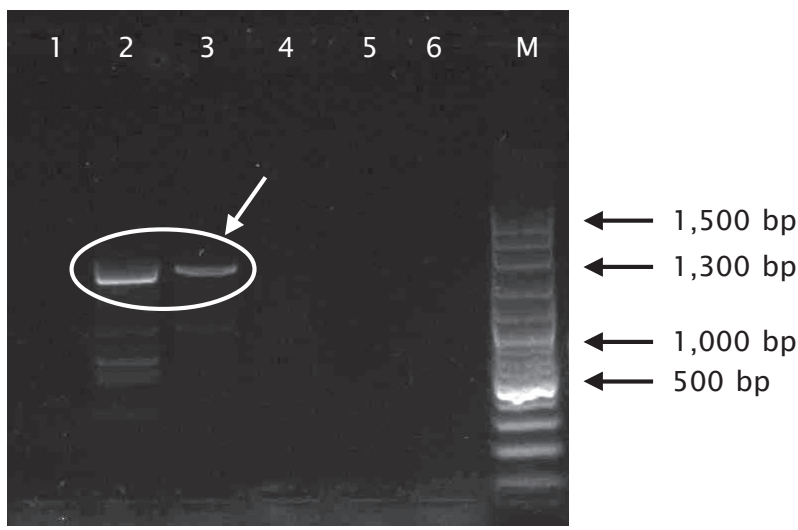

Gambar 7. Analisis integrasi gen PaCs di dalam thalus K. alvarezii yang ditransformasi dengan A. tumefaciens menggunakan PCR. PCR menggunakan kombinasi primer F PaCs dan $\mathrm{R}$ PaCs. Lajur $\mathrm{M}=$ Marker 100 bp plus, $1=$ non transgenik, $2=\mathrm{RL}$ transgenik putatif (1), $3=\mathrm{RL}$ transgenik putatif (2), $4 \& 5=\mathrm{RL}$ transgenik (pucat), $6=\mathrm{RL}$ transgenik (mati)

Figure 7. Electrophoresis of DNA genome K. alvarezii citrate syntase (PaCs) gene detection in A. tumefaciens transformed thalli K. alvarezii by PCR method. PCR product using F PaCs and R PaCs primers. $M=100$ bp plus DNA marker, $1=$ non transgenic, 2 = putatif transgenic (1), 3 = putatif transgenic (2), $4 \& 5=$ transgenic explant (pale), 6 = transgenic explant (dead)

kombinasi primer $35 \mathrm{sF}$ dan $R$ PaCs menghasilkan pita berukuran 1.630 bp pada $K$. alvarezii tetapi tidak menghasilkan amplikon pada K. alvarezii non transgenik (Gambar 8) (Daud et al., 2013). Hasil analisis ini menunjukkan bahwa gen $\mathrm{PaCs}$ pada K. alvarezii transgenik putatif di bawah kendali promoter 35S CaMV. Jadi, satu tunas K. alvarezii transgenik yang diambil secara acak dari tunas yang telah diisolasi DNA-nya adalah transgenik. Kombinasi primer ini juga digunakan untuk analisis integrasi gen $\mathrm{PaCs}$ pada Nicotiana tabacum dan Jatropha curcas (Tistama, 2012).

\section{KESIMPULAN}

Regenerasi rumput laut hasil transformasi gen $\mathrm{PaCs}$ paling baik dipelihara pada media cair yang diperkaya dengan pupuk PES, dengan derajat keasaman $\mathrm{pH}=6$; dan photopheriod 12:12. Gen PaCs telah berhasil diintroduksikan dan terintegrasi di dalam genom 


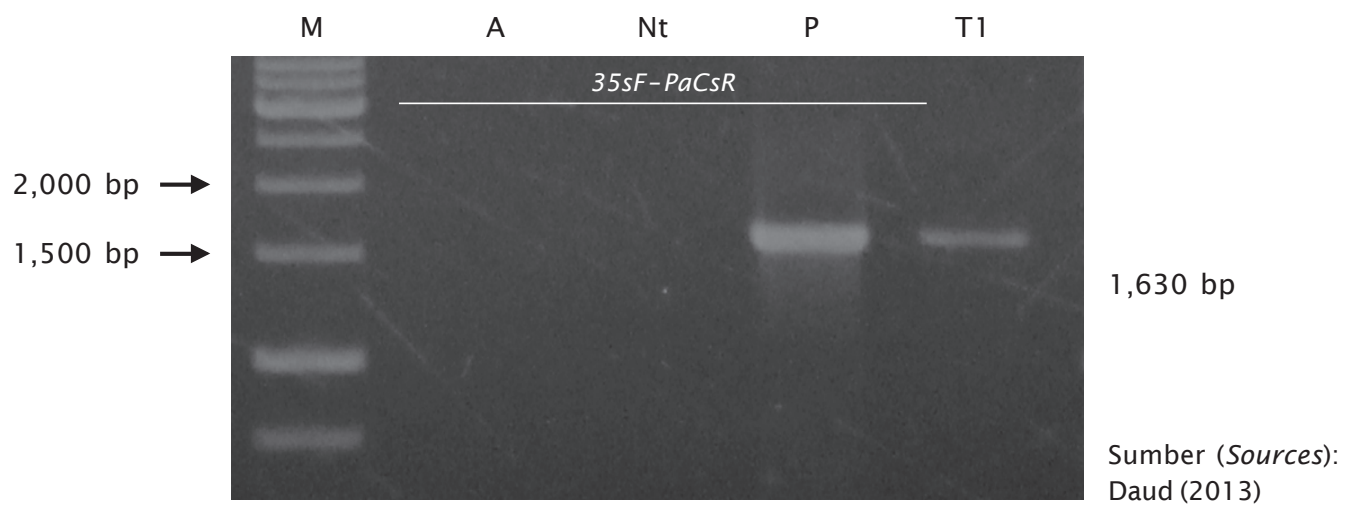

Gambar 8. Hasil elektroforesis DNA genom rumput laut $K$. alvarezii menggunakan primer $\mathrm{F} 35 \mathrm{~s}$ dan $\mathrm{R}$ PaCs. Lajur $\mathrm{M}=$ Marker $1 \mathrm{~kb}, \mathrm{~A}=$ kontrol air, $\mathrm{P}=$ kontrol + plasmid, $\mathrm{T} 1$ = Rumput laut transgenik putatif, $\mathrm{Nt}=$ non transgenik

Figure 8. Electrophoresis of DNA genome K. alvarezii transformed thalli K. alvarezii by PCR method. $P C R$ product using $F 35 s$ dan $R$ PaCs primers. $M=1 \mathrm{~kb} D N A$ marker, $A=$ negative control (water), $P=$ positive control (plasmid pMSH1-PaCs), $T 1$ = putative transgenic, $N t=$ non-transgenic

rumput laut $K$. alvarezii di bawah kendali promoter 35S CaMV pada 1.300 bp dan 1.630 bp menggunakan primer $\mathrm{F} 35 \mathrm{~s}$ dan $\mathrm{R} \mathrm{PaCs}$.

\section{DAFTAR ACUAN}

Buch, A.D., Archana, G., \& Kumar, N.G. 2008. Metabolic channeling of glucose towards gluconate in phosphate-solubilizing Pseudomonas aeruginosa $\mathrm{p} 4$ under phosporous deficiency. Res. Microb., 159: 635642.

Cheney, D., Metz, B., \& Stiller, J. 2011 . Agrobacterium-mediated genetic transformation in the macroscopic marine red algae Porphyra yezoensis. J. Phycol., 37: 11-13.

Cheng, R., Ruijuan, M.A., Ke, L., Hui, R., Xiangzhi, L., Zhaokai, W., Shanjun, Y., \& Yong, M. 2011. Agrobacterium tumefaciens mediated transformation of marine microalgae Schizochytrium. Micres., 25,421: 1-8.

Collen, J.U. 1995. Farming and physiology of the red algae Eucheuma growing commercial importance in East Africa. Ambio., 24: 7-8.

Daud, R.F., Widyastuti, U., Suharsono, Suryati, E., \& Parenrengi, A. 2013. Introduksi gen sitrat sintase ke dalam rumput laut Kappaphycus alvarezii menggunakan bakteri Agrobacterium tumefaciens. J. Ris. Akuakultur, 8(2): 201-208.

Da Silva, J.A. \& Fukasi, S. 2001. The impact of carbenicillin, cefotaxime and vancomycin on chrysanthemun and tobacco morphogenesis and Agrobacterium growth. J. Appl. Hort., 3(I): 3-12.

De Baar, H.J.W. \& La Roche, J. 2003. Metals in the oceans; evolution, biology and global change. Springer Verlag. Berlin (DE), p. 79105.

Diantariani, N.P., Sudiarta, I W., \& Elantiani, N.K. 2008. Proses biosorpsi dan desorpsi ion $\mathrm{Cr}$ (IV) pada biosorben rumput laut Eucheuma spinosum. Jurnal Kimia, 2(1): 45-52.

Handayani, T. 2013 . Konstruksi vektor biner dan transformasi gen lisozim pada rumput laut Kappaphycus alvarezii menggunakan perantara Agrobacterium tumefaciens. Seminar hasil sekolah pasca sarjana. Bogor (ID). Institut Pertanian Bogor. Bogor, $27 \mathrm{hlm}$.

Hiei, Y. \& Komari, T. 2008. Agrobacterium-mediated transformation of rice using immature embryos or calli induced from mature seed. Nature Protocol, 3(5): 824-826.

Jickells, T. 1995. Atmospheric inputs of metals and nutrients to the oceans: their magnitude and effects. Marine Chem., 48(3-4): 199-214.

Joubert, Y. \& Fleurence, J. 2005. DNA isolation protocol for seaweeds. Plant Mol. Biol. Rep., 23: 197a-197g.

Koronfel, M. 1998. Effects of the antibiotics kanamycin, cefotaxime, and carbenicillin on the differentiation of flax hypocotyls. Arab J. Biotechnol., 1(1): 93-98. 
Largo, D.B., Faukami, K., Adachi, M., \& Nhisijima, T. 1997. Direct enumeration of total bacteria from macroalgae by epifluoresecence microscopy as apllied to the flashy red algae Kappaphycus alvarezii and Glacilaria spp. (Rhodophyta). J. Phycol., 33: 554-557.

Mtolera, M.S.P., Collén, J., Pedersen, M., \& Semesi, A.K. 1995. Destructive hydrogen peroxide production in Eucheuma denticulatum (Rhodophyta) during stress caused by elevated $\mathrm{pH}$, high light intensities and competition with other species. Eur. J. Phycol., 30: 289-297.

Nagy, N.E., Dalen, L.R., Jones, D.L., Swensen, B., Fossdal, C.G., \& Eldhuset, T.D. 2004. Cytologycal an enzymatic responses to aluminum stress in root tips of norway spruce seedlings. New Phytol., 163(3): 595607.

Okkels, F.T. \& Padersen, M.G. 1988. The toxicity to plant tissue and to Agrobacterium tumefaciens of some antibiotic. Acta. Hort., 255: 199-207.

Rochyatun, E. \& Rozak, A. 2007. Pemantauan kadar logam berat dalam sedimen di perairan Teluk Jakarta. Makara, Sains, 11 (1): 28-36.
Suryati, E. \& Mulyaningum, S.R.H. 2009. Regenerasi rumput laut Kappaphycus alvarezii (Doty) melalui induksi kalus dan embrio dengan penambahan hormon perangsang tumbuh secara In vitro. J. Ris. Akuakultur, 4(1): 39-45.

Taiz, L. \& Zeiger. 2002. Plant Physiolgy. $3^{\text {th }}$ edition. Sinauier Associated Inc. Publishers. Sunderland Massachusetts, $637 \mathrm{pp}$.

Tistama, R. 2012. Isolasi dan introduksi gen sitrat sintase dari Pseudomonas aeruginosa ke dalam tanaman untuk meningkatkan toleransi terhadap cekaman aluminium. Disertasi. Bogor (ID): Institut Pertanian Bogor.

Vairappan, C.S. 2006. Seasonal occurrecences of epiphytic algae on the commercially cultivated red algae Kappaphycus alvarezii (Soliriciae, Gigartinales, Rhodophyta). J. Appl. Phycol., 18:611-617.

Yamamoto, Y., Kobayashi, Y., \& Matsumoto, H. 2001 . Lipid peroxidation is an early symptom triggered by aluminum, but not the primary cause of elongation inhibition in pea roots. Plant Physiol., 125: 199-208. 